\title{
Genome sequence and description of Nesterenkonia massiliensis sp. nov. strain $\mathrm{NP1}^{\mathrm{T}}$
}

\author{
Sophie Edouard ${ }^{1 *}$, Senthil Sankar ${ }^{1 *}$, Nicole Prisca Makaya Dangui ${ }^{1}$, Jean-Christophe Lagier ${ }^{1}$, \\ Caroline Michelle ${ }^{1}$, Didier Raoult ${ }^{1,2}$ and Pierre-Edouard Fournier ${ }^{1 *}+$ \\ ${ }^{1}$ Aix-Marseille Université, Faculté de médecine, Marseille, France. \\ ${ }^{2}$ Special Infectious Agents Unit, King Fahd Medical Research Center, King Abdulaziz Uni- \\ versity, Jeddah, Saudi Arabia \\ tThese 2 authors contributed equally \\ *Correspondence: pierre-edouard.fournier@univ-amu.fr
}

Keywords: Nesterenkonia massiliensis, genome, culturomics, taxono-genomics

\begin{abstract}
Nesterenkonia massiliensis sp. nov., strain $\mathrm{NP}^{\top}{ }^{\top}$, is the type strain of Nesterenkonia massiliensis sp. nov., a new species within the genus Nesterenkonia. This strain, whose genome is described here, was isolated from the feces of a 32-year-old French woman suffering from AIDS and living in Marseille. Nesterenkonia massiliensis is a Gram-positive aerobic coccus. Here, we describe the features of this bacterium, together with the complete genome sequencing and annotation. The 2,726,371 bp long genome (one chromosome but no plasmid) contains 2,663 protein-coding and 51 RNA genes, including 1 rRNA operon.
\end{abstract}

\section{Introduction}

Nesterenkonia massiliensis strain NP1 ${ }^{\mathrm{T}}$ (= CSUR $\mathrm{P} 244=$ DSM 26221) is the type strain of $N$. massiliensis sp. nov. This bacterium is a Grampositive, non-spore-forming, aerobic and motile coccus that was isolated from the fecal flora of AIDS-infected French female living in Marseille, France, as part of a "culturomics" study aiming at cultivating as many of the bacterial species in human feces as possible [1,2].

Taking advantage of the availability of more than 12,000 bacterial genome sequences [3], we recently proposed to use genomic properties in combination with phenotypic characteristics for the taxonomic classification of Bacteria [4-34].

Herein, we present a summary classification and a set features for Nesterenkonia massiliensis sp. nov., strain NP1T ${ }^{\mathrm{T}}$ (CSUR= P244 = DSM 26221), including the description of its complete genome and annotation. These characteristics support the circumscription of the species Nesterenkonia massiliensis.

The genus Nesterenkonia was first described by Stackebrandt et al. in 1995 [35]. This genus belongs to the family Micrococcaceae within the phylum Actinobacteria, and is most closely related to the genera Micrococcus, Arthrobacter and Kocuria [35]. The Nesterenkonia genus includes Grampositive, non spore-forming, aerobic, mesophilic bacteria that may be halotolerant or halophilic. Currently, the genus Nesterenkonia includes 12 species with validly published names [36]. Members of the genus Nesterenkonia are ubiquitous bacteria, which have been isolated from various environments including hypersaline soil and lakes, soda lakes, sea food, and paper and cotton pulp mills [36-40]. However, prior to our study, Nesterenkonia species had not been reported in humans, with the exception of DNA sequences from Nesterenkonia sp. detected in the gut microbiota of patients with chronic kidney diseases [41].

\section{Classification and features}

A stool sample was collected from a Caucasian, AIDS-infected, 32-year-old French woman living in Marseille, France. The patient gave an informed and signed consent. This study and the assent procedure were approved by the Ethics Committee of the Institut Fédératif de Recherche IFR48, Faculty of Medicine, Marseille, France under agreement number 09-022. The fecal sample was preserved 
at $-80^{\circ} \mathrm{C}$ after collection. Strain $\mathrm{NP}^{\mathrm{T}}$ (Table 1 ) was first isolated in March 2012 by cultivation on Columbia agar (BioMerieux, Marcy l'Etoile, France) under aerobic conditions after 14 days of preincubation of the stool sample with addition of $5 \mathrm{ml}$ of sheep rumen in blood bottle culture. The strain exhibited a $96.7 \% 16 \mathrm{~S}$ rRNA nucleotide sequence identity with $N$. alba [51], the phylogenetically most closely related Nesterenkonia species with standing in nomenclature (Figure 1). This value was lower than the 98.7\% 16S rRNA gene sequence threshold recommended by Stackebrandt and Ebers to delineate a new species without carrying out DNA-DNA hybridization

Table 1. Classification and general features of Nesterenkonia massiliensis strain NP1 ${ }^{\mathbf{T}}$ according to the MIGS recommendations [42].

\begin{tabular}{|c|c|c|c|}
\hline MIGS ID & Property & Term & Evidence code $^{a}$ \\
\hline & & Domain Bacteria & TAS $[43]$ \\
\hline & & Phylum Actinobacteria & TAS $[44]$ \\
\hline & & Class Actinobacteria & TAS $[45]$ \\
\hline & & Order Actinomycetales & TAS $[45-48]$ \\
\hline & & Family Micrococcaceae & TAS $[45-47,49]$ \\
\hline & & Genus Nesterenkonia & TAS $[35,39,45]$ \\
\hline & & Species Nesterenkonia massiliensis & IDA \\
\hline & Current classification & Type strain: NP1 & IDA \\
\hline & Gram stain & Positive & IDA \\
\hline & Cell shape & Cocci & IDA \\
\hline & Motility & Motile & IDA \\
\hline & Sporulation & Nonsporulating & IDA \\
\hline & $\begin{array}{l}\text { Temperature range } \\
\text { Optimum tempera- } \\
\text { ture }\end{array}$ & Unknown & $\begin{array}{l}\text { IDA } \\
\text { IDA }\end{array}$ \\
\hline MIGS-6.3 & Salinity & Halophilic & IDA \\
\hline \multirow[t]{3}{*}{ MIGS-22 } & Oxygen requirement & Aerobic & IDA \\
\hline & Carbon source & Unknown & NAS \\
\hline & Energy source & Unknown & NAS \\
\hline MIGS-6 & Habitat & Human gut & IDA \\
\hline MIGS-15 & Biotic relationship & Free living & IDA \\
\hline \multirow[t]{3}{*}{ MIGS-14 } & Pathogenicity & Unknown & \\
\hline & Biosafety level & 2 & \\
\hline & Isolation & Human feces & \\
\hline MIGS-4 & $\begin{array}{l}\text { Geographic location } \\
\text { Sample collection }\end{array}$ & Marseille, France & IDA \\
\hline MIGS-5 & $\begin{array}{l}\text { time } \\
\text { Latitude }\end{array}$ & $\begin{array}{l}\text { March } 2012 \\
43.296482\end{array}$ & IDA \\
\hline MIGS-4.1 & Longitude & 5.36978 & IDA \\
\hline MIGS-4.3 & Depth & Surface & IDA \\
\hline MIGS-4.4 & Altitude & $0 \mathrm{~m}$ above sea level & IDA \\
\hline
\end{tabular}

aEvidence codes - IDA: Inferred from Direct Assay; TAS: Traceable Author Statement (i.e., a direct report exists in the literature); NAS: Non-traceable Author Statement (i.e., not directly observed for the living, isolated sample, but based on a generally accepted property for the species, or anecdotal evidence). These evidence codes are from the Gene 
Ontology project [50]. If the evidence is IDA, then the property was directly observed for a live isolate by one of the authors or an expert mentioned in the acknowledgements.

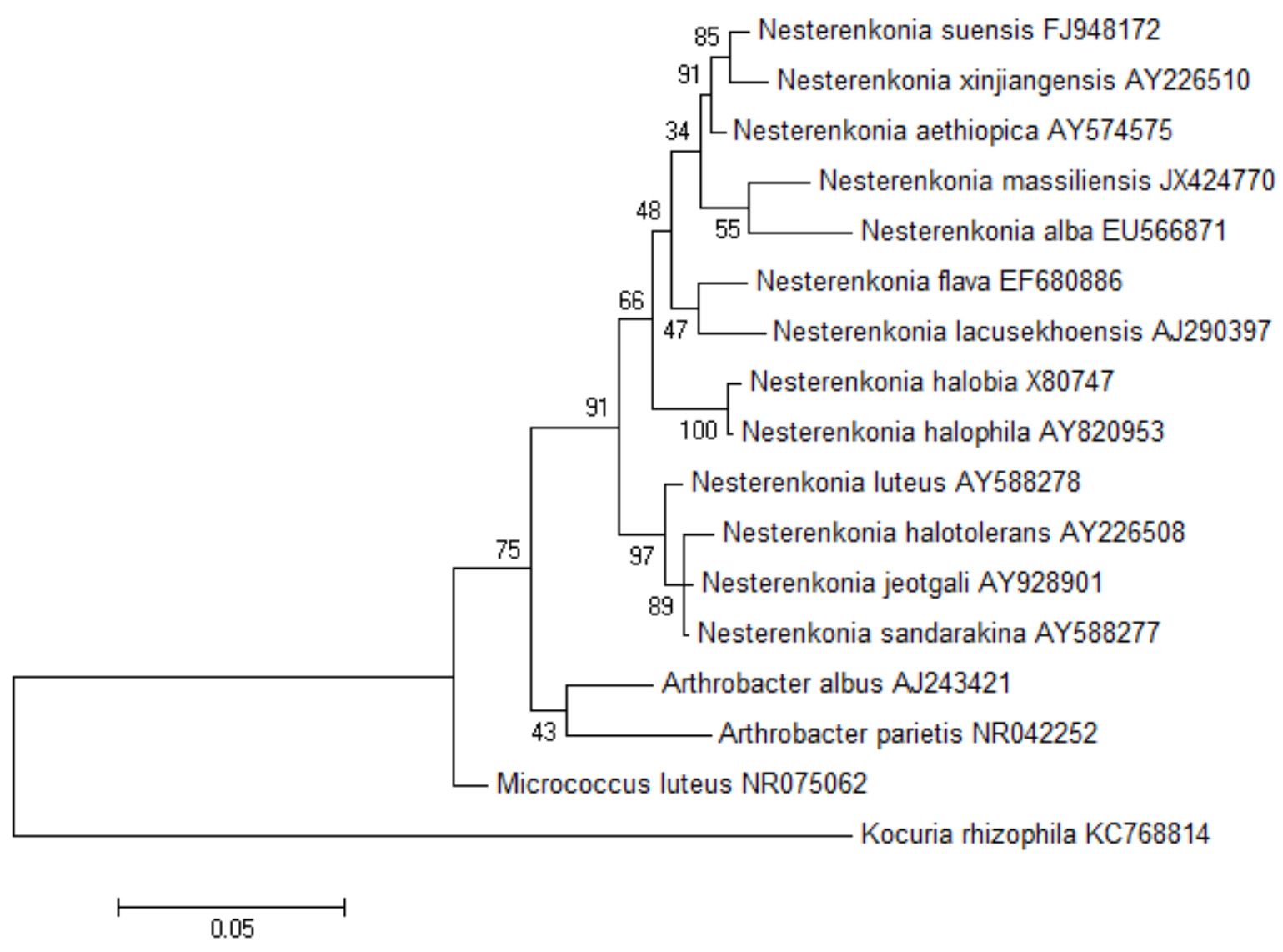

Figure 1: Consensus phylogenetic tree highlighting the position of Nesterenkonia massiliensis strain NP1 ${ }^{\mathrm{T}}$ relative to other type strains within the Nesterenkonia genus. Genbank accession numbers are indicated for each species. Sequences were aligned using CLUSTALW and phylogenetic inferences obtained using the maximum-likelihood method in the MEGA software package. Numbers at the nodes are percentages of bootstrap values from 500 replicates that support the node. Micrococcus luteus was used as the outgroup. The scale bar represents a $5 \%$ nucleotide sequence divergence. 

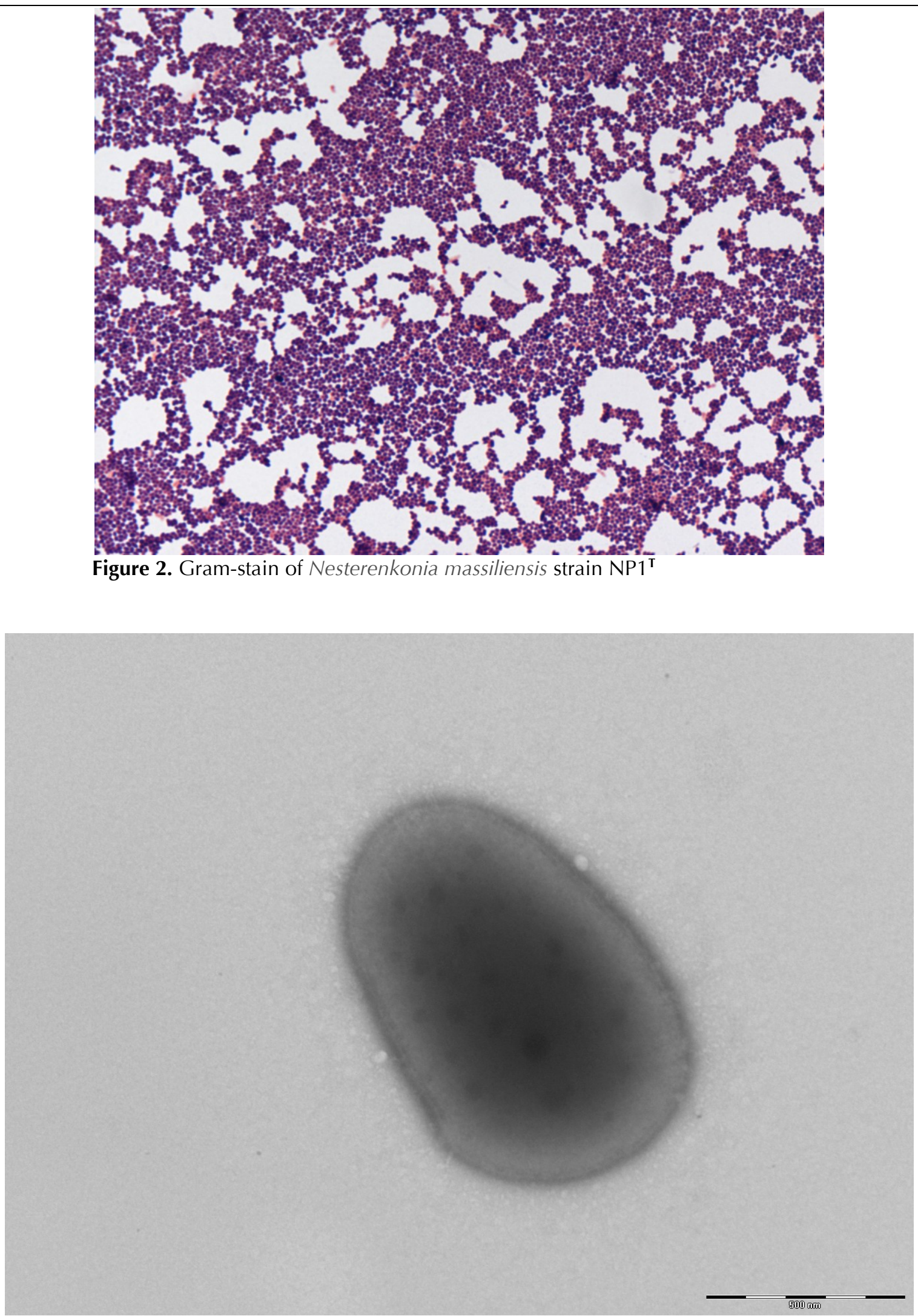

Figure 3. Transmission electron micrograph of $N$. massiliensis strain $\mathrm{NP}^{\mathrm{T}}$, made using a Morgani 268D (Philips) at an operating voltage of $60 \mathrm{kV}$. The scale bar represents $500 \mathrm{~nm}$.

Four different growth temperatures $(25,30,37$, $45^{\circ} \mathrm{C}$ ) were tested. Growth was observed between
25 and $45^{\circ} \mathrm{C}$ on blood-enriched Columbia agar (BioMerieux), with optimal growth occurring at 
$37^{\circ} \mathrm{C}$ after 24 hours of incubation. Colonies were dark yellow and $1 \mathrm{~mm}$ in diameter. Growth of the strain was tested under anaerobic and microaerophilic conditions using GENbag anaer and GENbag microaer systems, respectively (BioMerieux), and under aerobic conditions, with or without $5 \% \mathrm{CO}_{2}$. Optimal growth was obtained under aerobic conditions, but weak growth occurred in a microaerophilic atmosphere. No growth was observed under anaerobic conditions. Bacterial cells were Gram-positive (Figure 2), nonendospore-forming, and motile cocci. Cells grown on agar had a mean diameter and length of 0.67 $\mu \mathrm{m}$ and $1.4 \mu \mathrm{m}$, respectively (Figure 3 ).

Strain NP1T exhibited catalase but no oxidase activity. Using an API 20NE strip (BioMerieux), negative reactions were obtained for nitrate reduction, urease, indole production, glucose fermentation, arginine dihydrolase, $\beta$-galactosidase, glu- cose, arabinose, mannose, mannitol, N-acetylglucosamine, maltose, gluconate, caprate, adipate, malate, citrate, phenyl-acetate assimilation and cytochrome oxidase. Substrate oxidation and assimilation were examined with an API 50CH carbohydrate fermentation strip (BioMerieux) at $37^{\circ} \mathrm{C}$. Positive reactions were observed for Dglucose, D-fructose, D-saccharose, ribose, mannose, mannitol, D-trehalose and L-rhamnose. No reaction was observed for esculin, salicin, Dcellobiose and gentiobiose. N. massiliensis is susceptible to amoxicillin, imipenem, rifampin, ciprofloxacin, gentamicin, doxycycline and vancomycin but resistant to trimethoprim/sulfamethoxazole and metronidazole. When compared with representative species from the genus Nesterenkonia, $N$. massiliensis strain $\mathrm{NP}^{\mathrm{T}}$ differed in cell shape, colony color, motility, optimal growth temperature, and mannitol fermentation (Table 2).

Table 2. Differential characteristics of Nesterenkonia species*.

\begin{tabular}{|c|c|c|c|c|}
\hline & N. massiliensis & N. alba & N. flava & N. lacusekhoensis \\
\hline Cell diameter $(\mu \mathrm{m})$ & $0.7 \times 1.4$ & $0.4-0.6 \times 0.8-1.2$ & $0.6-0.8 \times 1.2-1.4$ & $0.8-0.9 \times 1-1.3$ \\
\hline Oxygen requirement & Aerobic & Aerobic & Aerobic & Aerobic \\
\hline Pigment production & Dark Yellow & White & Yellow & Bright yellow \\
\hline Gram stain & cocci & Short rods & Short rods & Short rods \\
\hline Optimal temperature $\left({ }^{\circ} \mathrm{C}\right)$ & $37^{\circ} \mathrm{C}$ & 42 & $40-42$ & $27-33.5$ \\
\hline Salt requirement & & & & \\
\hline $\mathrm{NaCl}$ tolerance (\%) & $0-3$ & $0-6$ & $0-10$ & $0-15$ \\
\hline Motility & + & - & - & - \\
\hline Endospore formation & - & - & - & - \\
\hline $\mathrm{H} 2 \mathrm{~S}$ production & - & - & - & W \\
\hline Indole production & - & - & - & - \\
\hline ONPG test* & NA & + & - & NA \\
\hline Citrate test & NA & - & - & W \\
\hline $\begin{array}{l}\text { Voges-Proskauer reaction } \\
\text { Production of }\end{array}$ & NA & - & - & - \\
\hline Catalase & + & + & + & + \\
\hline Oxidase & - & - & - & - \\
\hline Nitrate reductase & - & - & - & - \\
\hline Urease & - & - & - & NA \\
\hline $\begin{array}{l}\text { Balactosidase } \\
\text { Acid from }\end{array}$ & - & NA & - & NA \\
\hline L-arabinose & - & + & + & NA \\
\hline Mannose & - & - & + & + \\
\hline Mannitol & + & NA & - & - \\
\hline Sucrose & & + & + & + \\
\hline D-glucose & + & + & + & + \\
\hline D-fructose & + & - & + & + \\
\hline D-maltose & + & + & + & + \\
\hline D-lactose & - & - & - & - \\
\hline D-Galactose & - & - & - & - \\
\hline Trehalose & - & W & - & + \\
\hline
\end{tabular}




\begin{tabular}{lcccc}
\hline D-Xylose & - & - & - & - \\
Hydrolysis of: & & - & + & - \\
Starch & - & + & + & - \\
Gelatin & - & 60.2 & 65.5 & 66.1 \\
G+C content (mol\%) & 62.47 & Black liquor treatment & system of a cotton & Paper mill effluent, \\
& Human gut, & China & East Antarctica \\
Habitat & France & pull, China & & \\
\hline
\end{tabular}

+, Positive; -, negative; $W$, weak reaction; NA, not available.

* N. massiliensis strain NP, N. alba strain DSM 19423, N. flava strain JCM 14814 ${ }^{\top}$, N. lacusekhoensis strain DSM 12544

Matrix-assisted laser-desorption/ionization timeof-flight (MALDI-TOF) MS protein analysis was carried out as previously described [53] using a Microflex spectrometer (Brüker Daltonics, Leipzig, Germany). Twelve individual NP1 ${ }^{\mathrm{T}}$ colonies were deposited on a MTP 384 MALDI-TOF target plate (Brüker). The twelve spectra were imported into the MALDI BioTyper software (version 2.0, Brüker) and analyzed by standard pattern matching (with default parameter settings) against the main spectra of 4,706 bacteria, including 1 spec- trum from $N$. lacusekhoensis, the only validly named Nesterenkonia species for which a spectrum was available in the BioTyper database. A score enabled the presumptive identification and discrimination of the tested species from those in a database: a score $>2$ with a validated species enabled the identification at the species level; and a score $<1.7$ did not enable any identification. For strain $\mathrm{NP1}^{\mathrm{T}}$, no significant score was obtained, suggesting that our isolate was not a member of any known species (Figures 4 and 5).

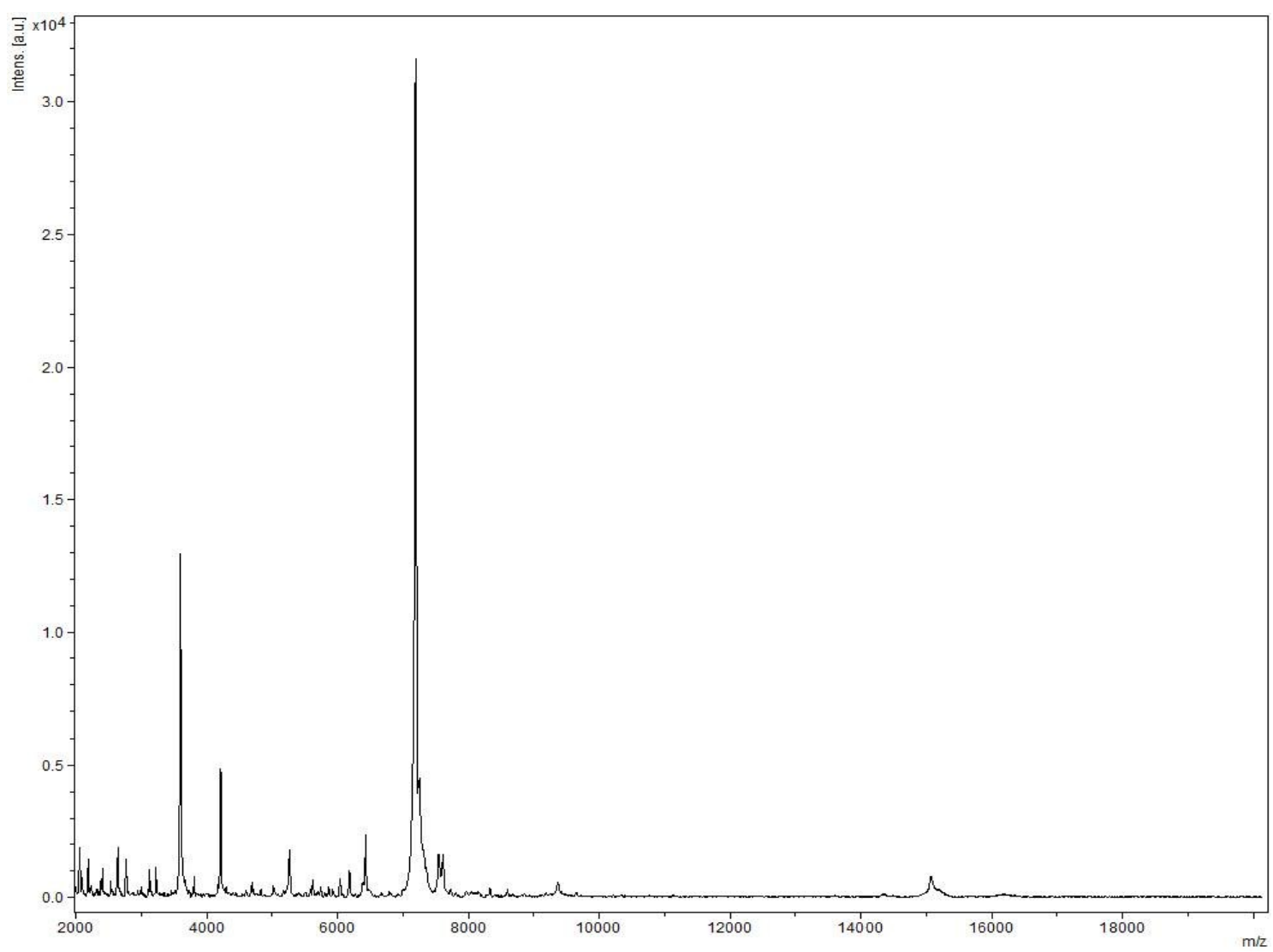

Figure 4. Reference mass spectrum from Nesterenkonia massiliensis strain $\mathrm{NP} 1^{\top}$. Spectra from 12 individual colonies were compared and a reference spectrum was generated. 
Nesterenkoniamassiliensis

Nesterenkonia lacusekhoensis 402 RLT

Micrococcus luteus 59 PIM

Kocuria rhizophila DSM 348

Arthrobacterparietis DSM $16404 \mathrm{~T}$

Arthrobacter albus

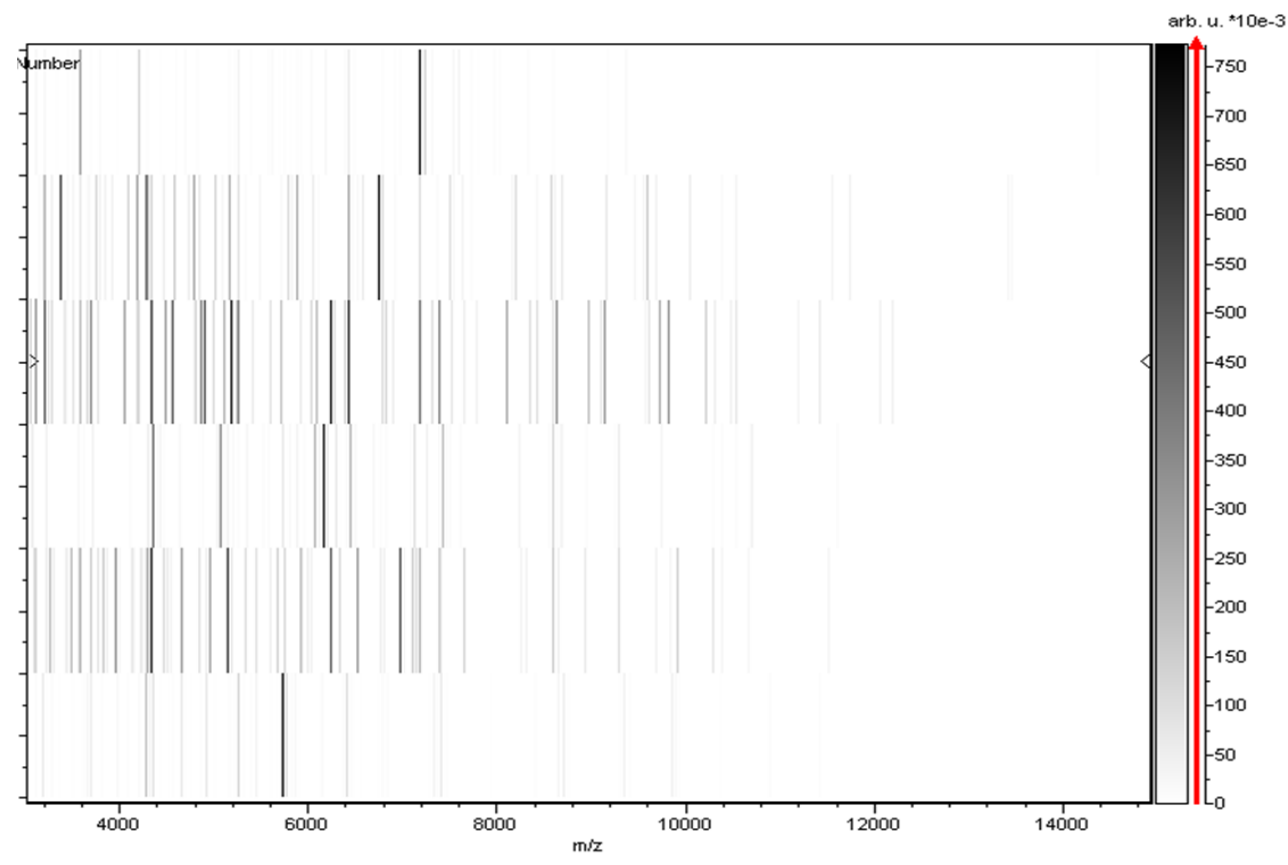

Figure 5. Gel view comparing $N$. massiliensis strain $\mathrm{NP}^{1}{ }^{\mathrm{T}}, \mathrm{N}$. lacusekhoensis and other species belonging to the family Micrococcaceae. The gel view displays the raw spectra of loaded spectrum files arranged as a pseudoelectrophoretic gel. The $\mathrm{x}$-axis records the $\mathrm{m} / \mathrm{z}$ value. The left $\mathrm{y}$-axis displays the running spectrum number originating from subsequent spectra loading. The peak intensity is expressed by a grey scale scheme. The grey scale on the right $y$-axis indicates the relative peak intensity in arbitrary units. Species names are on the left. 


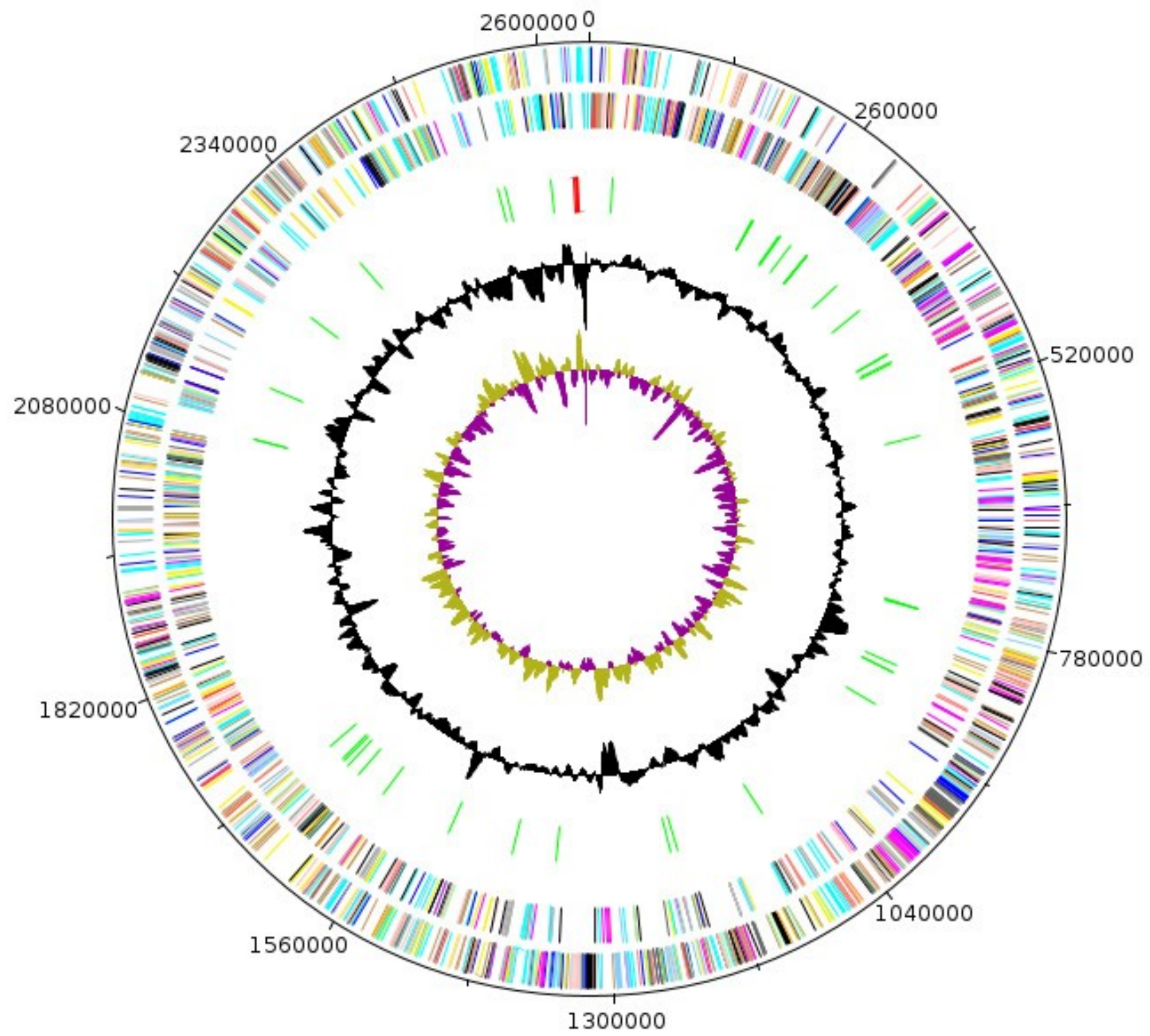

Figure 6. Graphical circular map of the chromosome. From the outside in, the outer two circles show open reading frames oriented in the forward (colored by COG categories) and reverse (colored by COG categories) directions, respectively. The third circle marks the rRNA gene operon (red) and tRNA genes (green). The fourth circle shows the $\mathrm{G}+\mathrm{C} \%$ content plot. The inner-most circle shows GC skew, purple indicating negative values and olive, positive values.

\section{Genome sequencing information}

\section{Genome project history}

The organism was selected for sequencing on the basis of its phylogenetic position, 16S rDNA similarity and phenotypic differences with other members of the genus Nesterenkonia, and is part of a "culturomics" study aiming at isolating individually all bacterial species within the human gut flora [1]. It was the third genome of a
Nesterenkonia species and the first genome of $N$. massiliensis sp. nov. A summary of the project information is shown in Table 3. The Genbank accession number is CBLL000000000 and consists of 141 contigs. Table 3 shows the project information and its association with MIGS version 2.0 compliance [42]. 


\begin{tabular}{lll}
\multicolumn{2}{l}{ Table 3. Project information } & Term \\
\hline MIGS ID & Property & High-quality draft \\
MIGS-31 & Finishing quality & One 454 paired-end 3-kb library \\
MIGS-28 & Libraries used & 454 GS FLX Titanium \\
MIGS-29 & Sequencing platforms & $22.63 \times$ \\
MIGS-31.2 & Fold coverage & Newbler version 2.5.3 \\
MIGS-30 & Assemblers & Prodigal \\
MIGS-32 & Gene calling method & PRJEB668 \\
& INSDC ID & CBLL000000000 \\
& Genbank ID & August 20, 2013 \\
& Genebank Date of release & Gi39432 \\
MIGS-13 & Gold ID & Study of human gut microbiome \\
\hline
\end{tabular}

\section{Growth conditions and DNA isolation}

N. massiliensis sp. nov strain NP1T ${ }^{\mathrm{T}}$ (= CSUR P244 = DSM 26221) was grown aerobically on sheep blood-enriched Columbia agar at $37^{\circ} \mathrm{C}$. Two petri dishes were spread and the colonies resuspended in $6 \times 100 \mu \mathrm{l}$ of G2 buffer (EZI DNA Tissue Kit, Qiagen). A first mechanical lysis was performed with glass powder on the Fastprep-24 device (Sample Preparation system, MP Biomedicals, USA) using $2 \times 20$ second bursts. DNA was incubated with $2.5 \mu \mathrm{g} / \mu \mathrm{L}$ of lysozyme for 30 minutes at $37^{\circ} \mathrm{C}$ and extracted using the BioRobot EZ 1 Advanced XL (Qiagen).The DNA was then concentrated and purified on a Qiamp kit (Qiagen). The DNA concentration measured by the Quant-it Picogreen kit (Invitrogen) on the Genios Tecan fluorometer was $94 \mathrm{ng} / \mu \mathrm{l}$.

\section{Genome sequencing and assembly}

DNA $(5 \mu \mathrm{g})$ was mechanically fragmented with a Hydroshear device (Digilab, Holliston, MA, USA) with an enrichment size at 3-4 kb. The DNA fragmentation was visualized through the Agilent 2100 BioAnalyzer on a DNA labchip 7500 with an average size of $3.5 \mathrm{~kb}$. The library was constructed using a 454 GS-FLX Titanium paired-end rapid library protocol. Circularization and nebulization generated a pattern with an average size of 390 bp. After 20 cycles of PCR amplification, the double stranded paired-end library was quantified using the Quant-it Ribogreen kit (Invitrogen) using a
Genios Tecan fluorometer at $820 \mathrm{pg} / \mu \mathrm{L}$. The library concentration equivalence was calculated as $3.86 \times 10^{9}$ molecules $/ \mu \mathrm{L}$. The library was stored at $-20^{\circ} \mathrm{C}$ until further use.

The library was clonally amplified with $1 \mathrm{cpb}$ in two emPCR reactions with the GS Titanium SV emPCR Kit (Lib-L) v2. The yield of the emPCR was $13.67 \%$, within the range of 5 to $20 \%$ recommended for the Roche procedure. Approximately 656,601 beads were loaded for a $1 / 4$ region on the GS Titanium PicoTiterPlate (PTP Kit 70x75, Roche) and sequenced with the GS Titanium Sequencing Kit XLR70. The run was performed overnight and analyzed on the cluster through the gsRunBrowser and Newbler assemblers (Roche). A total of 176,833 passed filter wells were obtained and generated $60.9 \mathrm{Mb}$ with an average of length of $345 \mathrm{bp}$. The passed filter sequences were assembled on Newbler with $90 \%$ identity and 40 bp as overlap. The final assembly identified 18 scaffolds and 141 large contigs (>1,500 bp), and generated a genome size of $2.69 \mathrm{Mb}$ which corresponds to a coverage of 22.63 genome equivalents.

\section{Genome annotation}

Open Reading Frames (ORFs) were predicted using Prodigal [54] with default parameters but the predicted ORFs were excluded if they spanned a sequencing gap region. The predicted bacterial protein sequences were searched against the GenBank database [55] and the Clusters of Orthol- 
Edouard et al.

ogous Groups (COG) databases using BLASTP. The tRNAScanSE tool [56] was used to find tRNA genes, whereas ribosomal RNAs were found by using RNAmmer [57] and BLASTn against the GenBank database. Lipoprotein signal peptides and the number of transmembrane helices were predicted using SignalP [58] and TMHMM [59] respectively. ORFans were identified if their BLASTP $E$-value was lower than $1 \mathrm{e}^{-3}$ for alignment length greater than 80 amino acids. If alignment lengths were smaller than 80 amino acids, we used an $E$ value of $1 \mathrm{e}^{-5}$. Such parameter thresholds have already been used in previous works to define ORFans. Artemis [60] and DNA Plotter [61] were used for data management and visualization of genomic features, respectively. The Mauve alignment tool (version 2.3.1) was used for multiple genomic sequence alignment [62]. To estimate the mean level of nucleotide sequence similarity at the genome level, we used the Average Genomic Identity of gene Sequences (AGIOS) home-made software [34]. Briefly, this software combines the Proteinortho software [63] for detecting orthologous proteins in pairwise comparisons of genomes, then retrieves the corresponding genes and determines the mean percentage of nucleotide sequence identity among orthologous ORFs using the Needleman-Wunsch global alignment algorithm. As only one genome was available for the genus Nesterenkonia, we used genomes from closely related genera for the calculation of AGIOS values. $N$. massiliensis strain $\mathrm{NT}^{\mathrm{T}}$ was compared to Nesterenkonia alba strain DSM 19423 (GenBank accession number ATXP00000000), Micrococcus luteus strain NCTC2665 (CP001628), Kocuria rhizophila strain DSM 2048 (AP009152) and Arthrobacter arilaitensis strain RE117 (FQ311875).

\section{Genome properties}

The genome of $N$. massiliensis strain $\mathrm{NP}^{\mathrm{T}}$ is 2,726,371bp long (1 chromosome, but no plasmid) with a $62.47 \% \mathrm{G}+\mathrm{C}$ content (Table 4, Figure 6, Figure 7). Of the 2,714 predicted genes, 2,663 were protein- coding genes, and 51 were RNAs. Three rRNA genes (one 16S rRNA, one 23S rRNA and one $5 \mathrm{~S}$ rRNA) and 48 predicted tRNA genes were identified in the genome. A total of 1,962 genes $(73.68 \%)$ were assigned a putative function. One hundred and ninety-nine genes were identified as ORFans $(7.47 \%)$. The remaining genes were annotated as hypothetical proteins. The properties and the statistics of the genome are summarized in Table 4. The distribution of genes into COGs functional categories is presented in Table 5 and a comparison is presented in Table 6.

Table 4. Nucleotide content and gene count levels of the genome

\begin{tabular}{lcc}
\hline Attribute & Value & \% of total \\
\hline Genome size (bp) & $2,726,371$ & 100 \\
DNA coding region (bp) & $2,473,018$ & 90.40 \\
DNA G+C content (bp) & $1,703,271$ & 62.47 \\
Total genes & 2714 & 100 \\
RNA genes & 51.88 \\
Protein-coding genes & 2663 & 98.12 \\
Genes with function prediction (Cogs + NR) & 1962 & 73.68 \\
Genes assigned to COGs & 1950 & 73.23 \\
Genes with peptide signals & 241 & 9.05 \\
Genes with transmembrane helices & 599 & 22.49 \\
\hline${ }^{a}$ The total is based on either the size of the genome in base pairs or the total number of protein coding genes \\
in the annotated genome.
\end{tabular}

http://standardsingenomics.org 
Table 5. Number of genes associated with the 25 general COG functional categories

\begin{tabular}{|c|c|c|c|}
\hline Code & Value & $\%$ age $^{a}$ & Description \\
\hline$J$ & 149 & 5,60 & Translation \\
\hline A & 1 & 0,04 & RNA processing and modification \\
\hline K & 162 & 6,08 & Transcription \\
\hline $\mathrm{L}$ & 188 & 7,06 & Replication, recombination and repair \\
\hline B & 1 & 0,04 & Chromatin structure and dynamics \\
\hline $\mathrm{D}$ & 20 & 0,75 & Cell cycle control, mitosis and meiosis \\
\hline Y & 0 & 0 & Nuclear structure \\
\hline V & 36 & 1,35 & Defense mechanisms \\
\hline $\mathrm{T}$ & 78 & 2,93 & Signal transduction mechanisms \\
\hline M & 112 & 4,21 & Cell wall/membrane biogenesis \\
\hline $\mathrm{N}$ & 3 & 0,11 & Cell motility \\
\hline Z & 0 & 0 & Cytoskeleton \\
\hline W & 0 & 0 & Extracellular structures \\
\hline$U$ & 29 & 1,09 & Intracellular trafficking and secretion \\
\hline $\mathrm{O}$ & 71 & 2,67 & Posttranslational modification, protein turnover, chaperones \\
\hline $\mathrm{C}$ & 129 & 4,84 & Energy production and conversion \\
\hline G & 148 & 5,56 & Carbohydrate transport and metabolism \\
\hline E & 239 & 8,97 & Amino acid transport and metabolism \\
\hline $\mathrm{F}$ & 67 & 2,52 & Nucleotide transport and metabolism \\
\hline $\mathrm{H}$ & 88 & 3,30 & Coenzyme transport and metabolism \\
\hline I & 73 & 2,74 & Lipid transport and metabolism \\
\hline $\mathrm{P}$ & 160 & 6,01 & Inorganic ion transport and metabolism \\
\hline Q & 48 & 1,80 & Secondary metabolites biosynthesis, transport and catabolism \\
\hline $\mathrm{R}$ & 293 & 11,00 & General function prediction only \\
\hline S & 142 & 5,33 & Function unknown \\
\hline - & 713 & 26,77 & Not in COGs \\
\hline
\end{tabular}

aThe total is based on the total number of protein coding genes in the annotated genome

\section{Genomic comparison}

We compared the genome of $N$. massiliensis strain $\mathrm{NP}^{\mathrm{T}}$ to those of $N$. alba strain DSM 19423, $M$. luteus strain NCTC2665, K. rhizophila strain DSM 2048 and A. arilaitensis strain RE117. The draft genome of $N$. massiliensis had a larger size than those of $N$. alba and M. luteus $(2.72,2.59$ and 2.7 $\mathrm{Mb}$, respectively) but was smaller than that of $A$. arilaitensis $(3.92 \mathrm{Mb})$. The $\mathrm{G}+\mathrm{C}$ content of $N$. massiliensis was lower than those of $N$. alba, M. luteus and $K$. rhizophila $(62.4,63.8,73$ and $71.2 \%$, respectively) but higher than that of $A$. arilaitensis (59.3\%). The gene content of $N$. massiliensis was larger than those of $N$. alba, M. luteus and $K$. rhizophila $(2,714,2,403,2,345$ and 2,414 genes, respectively) but smaller than that of $A$. arilaitensis $(3,771)$. In addition, $N$. massiliensis shared 1,142, 1,132, 1,087 and 1,208 orthologous genes with $N$. alba, M. luteus and K. rhizophila, respectively. N. massiliensis exhibited an AGIOS value 
Edouard et al.

of $75.61 \%$ with $N$. alba, and 68.57 to 70.5 with other members of the family Micrococcaceae.

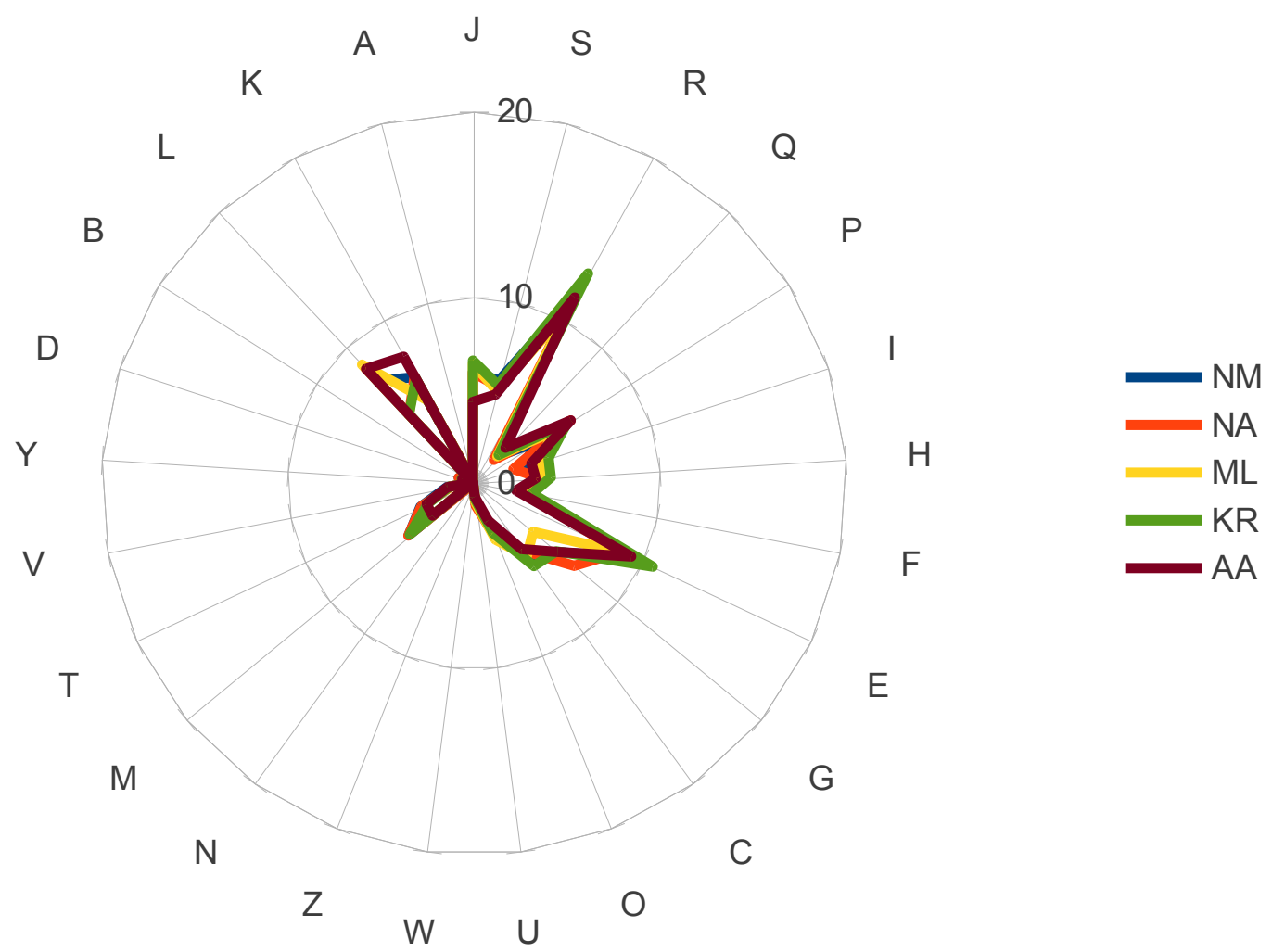

Figure 7. Distribution of functional classes of predicted genes on the chromosomes of Nesterenkonia massiliensis (NM), Nesterenkonia alba (NA), Micrococcus luteus (ML), Kocuria rhizophila (KR) and Arthrobacter arilaitensis (AA) according to the COG category. For each genome, we indicated the percentage of each gene category.

Table 6. Genomic comparison of N. massiliensis and 4 other members of the family Micrococcaceae ${ }^{\dagger}$.

\begin{tabular}{|c|c|c|c|c|c|}
\hline & $\begin{array}{r}\text { Nesterenkonia } \\
\text { massilensis }\end{array}$ & $\begin{array}{r}\text { Nesterenkonia } \\
\text { alba }\end{array}$ & $\begin{array}{r}\text { Micrococcus } \\
\text { luteus }\end{array}$ & $\begin{array}{r}\text { Kocuria } \\
\text { rhizophila }\end{array}$ & $\begin{array}{r}\text { Arthrobacter } \\
\text { arilaitensis }\end{array}$ \\
\hline $\begin{array}{l}\text { Nesterenkonia } \\
\text { massilensis }\end{array}$ & 2,663 & 1,142 & 1,132 & 1,087 & 1,208 \\
\hline $\begin{array}{l}\text { Nesterenkonia } \\
\text { alba }\end{array}$ & 75.61 & 2,351 & 1,046 & 1,033 & 1,116 \\
\hline $\begin{array}{l}\text { Micrococcus } \\
\text { luteus }\end{array}$ & 70.5 & 1,046 & 2,236 & 1,152 & 1,241 \\
\hline $\begin{array}{l}\text { Kocuria } \\
\text { rhizophila }\end{array}$ & 69.76 & 69.96 & 74.23 & 2,357 & 1,224 \\
\hline $\begin{array}{l}\text { Arthrobacter } \\
\text { arilaitensis }\end{array}$ & 68.57 & 68.04 & 69.35 & 69.05 & 3,436 \\
\hline
\end{tabular}

${ }^{\dagger}$ Upper right, numbers of orthologous proteins shared between genomes; lower left, AGIOS values; bold numbers indicate the numbers of proteins per genome.

\section{Conclusion}


On the basis of phenotypic, phylogenetic and genomic analyses, we formally propose the creation of Nesterenkonia massiliensis sp. nov. that contains the strain NP1 ${ }^{\mathrm{T}}$. The strain has been isolated from the fecal flora of an AIDS-infected patient living in Marseille, France. Several other bacterial species were also cultivated from different fecal samples through diversification of culture conditions [434], thus suggesting that the human fecal flora of humans remains only partially known.

\section{Description of Nesterenkonia massiliensis sp. nov.}

Nesterenkonia massiliensis (mas.si.li.en'sis. L. gen. fem. n. massiliensis of Massilia, the Roman name of Marseille, France, where the type strain was isolated).

Grows between 25 and $45^{\circ} \mathrm{C}$ on blood-enriched Columbia agar (BioMerieux). Optimal growth obtained at $37^{\circ} \mathrm{C}$ in aerobic atmosphere. Weak growth in microaerophilic atmosphere. No growth under anaerobic condition. Colonies are dark yellow and $1 \mathrm{~mm}$ in diameter. Cells are Grampositive, non-endospore-forming, and motile cocci, with a mean diameter and length of $0.67 \mu \mathrm{m}$ and $1.4 \mu \mathrm{m}$, respectively. Catalase positive, oxidase negative. Negative reactions obtained for nitrate reduction, urease, indole production, glucose

\section{References}

1. Lagier JC, Armougom F, Million M, Hugon P, Pagnier I, Robert C, Bittar F, Fournous G, Gimenez G, Maraninchi M, et al. Microbial culturomics: paradigm shift in the human gut microbiome study. Clin Microbiol Infect 2012; 18:1185-1193. PubMed

2. Dubourg G, Lagier JC, Armougom F, Robert C, Hamad I, Brouqui P, Raoult D. The gut microbiota of a patient with resistant tuberculosis is more comprehensively studied by culturomics than by metagenomics. Eur J Clin Microbiol Infect 2013; 32:637-645. PubMed http://dx.doi.org/10.1007/s10096-012-1787-3

3. Database GOLD.

http://www.genomesonline.org/cgibin/GOLD/index.cgi

4. Ramasamy D, Mishra AK, Lagier JC, Padhmanabhan R, Rossi-Tamisier M, Sentausa E, Raoult D, Fournier PE. A polyphasic strategy incorporating genomic data for the taxonomic description of new bacterial species. Int J Syst Evol fermentation, arginine dihydrolase, $\beta$ galactosidase, glucose, arabinose, mannose, mannitol, N-acetyl-glucosamine, maltose, gluconate, caprate, adipate, malate, citrate, phenylacetate assimilation and cytochrome oxidase. Fermentation of D-glucose, D-fructose, Dsaccharose, ribose, mannose, mannitol, Dtrehalose and L-rhamnose. No reaction observed for esculin, salicin, D-cellobiose and gentiobiose. Cells are susceptible to amoxicillin, imipenem, rifampin, ciprofloxacin, gentamicin, doxycycline and vancomycin but resistant to trimethoprim/sulfamethoxazole and metronidazole.

The $\mathrm{G}+\mathrm{C}$ content of the genome is $62.47 \%$. The $16 \mathrm{~S}$ rRNA and genome sequences are deposited in GenBank under accession numbers JX424770 and CBLL00000000, respectively. The habitat of the microorganism is the human digestive tract. The type strain NP1 $1^{\mathrm{T}}$ (= CSUR P244 = DSM 26221) was isolated from the fecal flora of a 32-year-old French female suffering from AIDS.

\section{Acknowledgements}

The authors thank the Xegen Company (www.xegen.fr) for automating the genomic annotation process. This study was funded by the Mediterranée-Infection Foundation.

Microbiol 2014; (In press). PubMed http://dx.doi.org/10.1099/ijs.0.057091-0

5. Roux V, Million M, Robert C, Magne A, Raoult D. Non-contiguous finished genome sequence and description of Oceanobacillus massiliensis sp. nov. Stand Genomic Sci 2013; 9:370-384. http://dx.doi.org/10.4056/sigs.4267953

6. Kokcha S, Mishra AK, Lagier JC, Million M, Leroy Q, Raoult D, Fournier PE. Non contiguousfinished genome sequence and description of $\mathrm{Ba}-$ cillus timonensis sp. nov. Stand Genomic Sci 2012; 6:346-355. PubMed http://dx.doi.org/10.4056/sigs.2776064

7. Lagier JC, El Karkouri K, Nguyen TT, Armougom F, Raoult D, Fournier PE. Non-contiguous finished genome sequence and description of Anaerococcus senegalensis sp. nov. Stand Genomic Sci 2012; 6:116-125. PubMed http://dx.doi.org/10.4056/sigs.2415480

8. Mishra AK, Gimenez G, Lagier JC, Robert C, Raoult D, Fournier PE. Genome sequence and description of Alistipes senegalensis sp. nov. Stand 
Edouard et al.

Genomic Sci 2012; 7:1-16. PubMed

http://dx.doi.org/10.4056/sigs.2956294

9. Lagier JC, Armougom F, Mishra AK, Nguyen TT, Raoult D, Fournier PE. Non-contiguous finished genome sequence and description of Alistipes timonensis sp. nov. Stand Genomic Sci 2012; 6:315-324. PubMed http://dx.doi.org/10.4056/sigs.2685971

10. Mishra AK, Lagier JC, Robert C, Raoult D, Fournier PE. Non-contiguous finished genome sequence and description of Clostridium senegalense sp. nov. Stand Genomic Sci 2012; 6:386-395. PubMed

11. Mishra AK, Lagier JC, Robert C, Raoult D, Fournier PE. Non contiguous-finished genome sequence and description of Peptoniphilus timonensis sp. nov. Stand Genomic Sci 2012; 7:111. PubMed http://dx.doi.org/10.4056/sigs.2956294

12. Mishra AK, Lagier JC, Rivet R, Raoult D, Fournier $P E$. Non-contiguous finished genome sequence and description of Paenibacillus senegalensis sp. nov. Stand Genomic Sci 2012; 7:70-81. PubMed http://dx.doi.org/10.4056/sigs.3056450

13. Lagier JC, Gimenez G, Robert C, Raoult D, Fournier PE. Non-contiguous finished genome sequence and description of Herbaspirillum massiliense sp. nov. Stand Genomic Sci 2012; 7:200-209. PubMed

14. Roux V, El Karkouri K, Lagier JC, Robert C, Raoult D. Non-contiguous finished genome sequence and description of Kurthia massiliensis sp. nov. Stand Genomic Sci 2012; 7:221-232. PubMed http://dx.doi.org/10.4056/sigs.3206554

15. Kokcha S, Ramasamy D, Lagier JC, Robert C, Raoult D, Fournier PE. Non-contiguous finished genome sequence and description of Brevibacterium senegalense sp. nov. Stand Genomic Sci 2012; 7:233-245. PubMed http://dx.doi.org/10.4056/sigs.3256677

16. Ramasamy D, Kokcha S, Lagier JC, Nguyen TT, Raoult D, Fournier PE. Genome sequence and description of Aeromicrobium massiliense sp. nov. Stand Genomic Sci 2012; 7:246-257. PubMed http://dx.doi.org/10.4056/sigs.3306717

17. Lagier JC, Ramasamy D, Rivet R, Raoult D, Fournier PE. Non contiguous-finished genome sequence and description of Cellulomonas massiliensis sp. nov. Stand Genomic Sci 2012; 7:258-270. PubMed http://dx.doi.org/10.4056/sigs.3316719
18. Lagier JC, Elkarkouri K, Rivet R, Couderc C, Raoult D, Fournier PE. Non contiguous-finished genome sequence and description of Senegalemassilia anaerobia gen. nov., sp. nov. Stand Genomic Sci 2013; 7:343-356. PubMed http://dx.doi.org/10.4056/sigs.3246665

19. Mishra AK, Hugon P, Lagier JC, Nguyen TT, Robert C, Couderc C, Raoult D, Fournier PE. Non contiguous-finished genome sequence and description of Peptoniphilus obesi sp. nov. Stand Genomic Sci 2013; 7:357-369. PubMed http://dx.doi.org/10.4056/sigs.32766871

20. Mishra AK, Lagier JC, Nguyen TT, Raoult D, Fournier PE. Non contiguous-finished genome sequence and description of Peptoniphilus senegalensis sp. nov. Stand Genomic Sci 2013; 7:370-381. PubMed http://dx.doi.org/10.4056/sigs.3366764

21. Lagier JC, El Karkouri K, Mishra AK, Robert C, Raoult D, Fournier PE. Non contiguous-finished genome sequence and description of Enterobacter massiliensis sp. nov. Stand Genomic Sci 2013; 7:399-412. PubMed http://dx.doi.org/10.4056/sigs.3396830

22. Hugon $\mathrm{P}$, Ramasamy D, Lagier JC, Rivet $\mathrm{R}$, Couderc C, Raoult D, Fournier PE. Non contiguous-finished genome sequence and description of Alistipes obesi sp. nov. Stand Genomic Sci 2013; 7:427-439. PubMed http://dx.doi.org/10.4056/sigs.3336746

23. Mishra AK, Hugon $P$, Robert $C$, Raoult $D$, Fournier PE. Non contiguous-finished genome sequence and description of Peptoniphilus grossensis sp. nov. Stand Genomic Sci 2012; 7:320-330. PubMed

24. Mishra AK, Hugon P, Lagier JC, Nguyen TT, Couderc C, Raoult D, Fournier PE. Non contiguous-finished genome sequence and description of Enorma massiliensis gen. nov., sp. nov., a new member of the Family Coriobacteriaceae. Stand Genomic Sci 2013; 8:290-305. PubMed http://dx.doi.org/10.4056/sigs.3426906

25. Ramasamy D, Lagier JC, Gorlas A, Raoult D, Fournier PE. Non contiguous-finished genome sequence and description of Bacillus massiliosenegalensis sp. nov. Stand Genomic Sci 2013; 8:264-278. PubMed http://dx.doi.org/10.4056/sigs.3496989

26. Ramasamy D, Lagier JC, Nguyen TT, Raoult D, Fournier PE. Non contiguous-finished genome sequence and description of Dielma fastidiosa gen. nov., sp. nov., a new member of the Family Erysipelotrichaceae. Stand Genomic Sci 2013; 
8:336-351. PubMed

http://dx.doi.org/10.4056/sigs.3567059

27. Mishra AK, Lagier JC, Robert C, Raoult D, Fournier PE. Genome sequence and description of Timonella senegalensis gen. nov., sp. nov., a new member of the suborder Micrococcinae. Stand Genomic Sci 2013; 8:318-335. PubMed http://dx.doi.org/10.4056/sigs.3476977

28. Mishra AK, Pfleiderer A, Lagier JC, Robert C, Raoult D, Fournier PE. Non contiguous-finished genome sequence and description of Bacillus massilioanorexius sp. nov. Stand Genomic Sci 2013; 8:465-479. PubMed http://dx.doi.org/10.4056/sigs.4087826

29. Hugon P, Mishra AK, Lagier JC, Nguyen TT, Couderc C, Raoult D, Fournier PE. Noncontiguous finished genome sequence and description of Brevibacillus massiliensis sp. nov. Stand Genomic Sci 2013; 8:1-14. PubMed http://dx.doi.org/10.4056/sigs.3466975

30. Hugon P, Mishra AK, Robert C, Raoult D, Fournier PE. Non-contiguous finished genome sequence and description of Anaerococcus vaginalis. Stand Genomic Sci 2012; 6:356-365. PubMed http://dx.doi.org/10.4056/sigs.2716452

31. Hugon P, Ramasamy D, Robert C, Couderc C, Raoult D, Fournier PE. Non-contiguous finished genome sequence and description of Kallipyga massiliensis gen. nov., sp. nov., a new member of the family Clostridiales Incertae Sedis XI. Stand Genomic Sci 2013; 8:500-515. PubMed http://dx.doi.org/10.4056/sigs.4047997

32. Padhmanabhan R, Lagier JC, Dangui NPM, Michelle C, Couderc C, Raoult D, Fournier PE. Non-contiguous finished genome sequence and description of Megasphaera massiliensis. Stand Genomic Sci 2013; 8:525-538. PubMed http://dx.doi.org/10.4056/sigs.4077819

33. Mishra AK, Edouard S, Dangui NPM, Lagier JC, Caputo A, Blanc-Tailleur C, Ravaux I, Raoult D, Fournier PE. Non-contiguous finished genome sequence and description of Nosocomiicoccus massiliensis sp. nov. Stand Genomic Sci 2013; 9:205-219. PubMed http://dx.doi.org/10.4056/sigs.4378121

34. Mishra AK, Lagier JC, Pfleiderer A, Nguyen TT, Caputo A, Raoult D, Fournier PE. Non-contiguous finished genome sequence and description of Holdemania massiliensis sp. nov. Stand Genomic Sci 2013; 9:395-409.

http://dx.doi.org/10.4056/sigs.4628316
35. Stackebrandt E, Koch C, Gvozdiak O, Schumann P. Taxonomic dissection of the genus Micrococcus: Kocuria gen. nov., Nesterenkonia gen. nov., Kytococcus gen. nov., Dermacoccus gen. nov., and Micrococcus Cohn 1872 gen. emend. Int J Syst Bacteriol 1995; 45:682-692. PubMed http://dx.doi.org/10.1099/00207713-45-4-682

36. Govender L, Naidoo L, Setati ME. Nesterenkonia suensis sp. nov., a haloalkaliphilic actinobacterium isolated from a salt pan. Int J Syst Evol Microbiol 2013; 63:41-46. PubMed http://dx.doi.org/10.1099/ijs.0.035006-0

37. Collins MD, Lawson PA, Labrenz M, Tindall BJ, Weiss N, Hirsch P. Nesterenkonia lacusekhoensis sp. nov., isolated from hypersaline Ekho Lake, East Antarctica, and emended description of the genus Nesterenkonia. Int I Syst Evol Microbiol 2002; 52:1145-1150. PubMed http://dx.doi.org/10.1099/ijs.0.02118-0

38. Li WJ, Zhang YQ, Schumann P, Liu HY, Yu LY, Zhang YQ, Stackebrandt E, Xu LH, Jiang CL. Nesterenkonia halophila sp. nov., a moderately halophilic, alkalitolerant actinobacterium isolated from a saline soil. Int J Syst Evol Microbiol 2008; 58:1359-1363. PubMed http://dx.doi.org/10.1099/ijs.0.64226-0

39. Li WJ, Chen HH, Kim CJ, Zhang YQ, Park DJ, Lee JC, Xu LH, Jiang CL. Nesterenkonia sandarakina sp. nov. and Nesterenkonia lutea sp. nov., novel actinobacteria, and emended description of the genus Nesterenkonia. Int I Syst Evol Microbiol 2005; 55:463-466. PubMed http://dx.doi.org/10.1099/ijs.0.63281-0

40. Li WJ, Chen HH, Zhang YQ, Schumann P, Stackebrandt E, Xu LH, Jiang CL. Nesterenkonia halotolerans sp. nov. and Nesterenkonia xinjiangensis sp. nov., actinobacteria from saline soils in the west of China. Int / Syst Evol Microbiol 2004; 54:837-841. PubMed http://dx.doi.org/10.1099/ijs.0.02935-0

41. Vaziri ND, Wong J, Pahl M, Piceno YM, Yuan J, DeSantis TZ, Ni Z, Nguyen TH, Andersen GL. Chronic kidney disease alters intestinal microbial flora. Kidney Int 2013; 83:308-315. PubMed http://dx.doi.org/10.1038/ki.2012.345

42. Field D, Garrity G, Gray T, Morrison N, Selengut J, Sterk P, Tatusova T, Thomson N, Allen MJ, Angiuoli SV, et al. The minimum information about a genome sequence (MIGS) specification. Nat Biotechnol 2008; 26:541-547. PubMed http://dx.doi.org/10.1038/nbt1360 
Edouard et al.

43. Woese CR, Kandler O, Wheelis ML. Towards a natural system of organisms: proposal for the domains Archaea, Bacteria, and Eucarya. Proc Natl Acad Sci USA 1990; 87:4576-4579. PubMed http://dx.doi.org/10.1073/pnas.87.12.4576

44. Garrity GM, Holt JG. The Road Map to the Manual. In: Garrity GM, Boone DR, Castenholz RW (eds), Bergey's Manual of Systematic Bacteriology, Second Edition, Volume 1, Springer, New York, 2001, p. 119-169.

45. Stackebrandt E, Rainey FA, Ward-Rainey NL. Proposal for a New Hierarchic Classification System, Actinobacteria classis nov. Int / Syst Bacteriol 1997; 47:479-491. http://dx.doi.org/10.1099/00207713-47-2-479

46. Zhi XY, Li WJ, Stackebrandt E. An update of the structure and 16S rRNA gene sequence-based definition of higher ranks of the class Actinobacteria, with the proposal of two new suborders and four new families and emended descriptions of the existing higher taxa. Int J Syst Evol Microbiol 2009; 59:589-608. PubMed http://dx.doi.org/10.1099/ijs.0.65780-0

47. Skerman VBD, McGowan V, Sneath PHA. Approved Lists of Bacterial Names. Int / Syst Bacteriol 1980; 30:225-420. http://dx.doi.org/10.1099/00207713-30-1-225

48. Buchanan RE. Studies in the Nomenclature and Classification of the Bacteria: II. The Primary Subdivisions of the Schizomycetes. I Bacteriol 1917; 2:155-164. PubMed

49. Pribram E. A Contribution to the classification of microorganisms. J Bacteriol 1929; 18:361-394. PubMed

50. Ashburner M, Ball CA, Blake JA, Botstein D, Butler H, Cherry JM, Davis AP, Dolinski K, Dwight SS, Eppig JT, et al. Gene ontology: tool for the unification of biology. The Gene Ontology Consortium. Nat Genet 2000; 25:25-29. PubMed http://dx.doi.org/10.1038/75556

51. Luo HY, Wang YR, Miao LH, Yang PL, Shi PJ, Fang CX, Yao B, Fan YL. Nesterenkonia alba sp. nov., an alkaliphilic actinobacterium isolated from the black liquor treatment system of a cotton pulp mill. Int / Syst Evol Microbiol 2009; 59:863868. PubMed http://dx.doi.org/10.1099/ijs.0.003376-0

52. Stackebrandt E, Ebers J. Taxonomic parameters revisited: tarnished gold standards. Microbiol Today 2006; 33:152-155.

53. Seng P, Drancourt M, Gouriet F, La Scola B, Fournier PE, Rolain JM, Raoult D. Ongoing revo- lution in bacteriology: routine identification of bacteria by matrix-assisted laser desorption ionization time-of-flight mass spectrometry. Clin Infect Dis 2009; 49:543-551. PubMed http://dx.doi.org/10.1086/600885 
54. Prodigal. http://prodigal.ornl.gov

55. Benson DA, Karsch-Mizrachi I, Clark K, Lipman DJ, Ostell J, Sayers EW. GenBank. Nucleic Acids Res 2012; 40:D48-D53. PubMed http://dx.doi.org/10.1093/nar/gkr1202

56. Lowe TM, Eddy SR. tRNAscan-SE: a program for improved detection of transfer RNA genes in genomic sequence. Nucleic Acids Res 1997;

25:955-964. PubMed http://dx.doi.org/10.1093/nar/25.5.0955

57. Lagesen K, Hallin P, Rødland EA, Staerfeldt HH, Rognes T, Ussery DW. RNAmmer: consistent and rapid annotation of ribosomal RNA genes. Nucleic Acids Res 2007; 35:3100-3108. PubMed http://dx.doi.org/10.1093/nar/gkm160

58. Bendtsen JD, Nielsen H, von Heijne G, Brunak S. Improved prediction of signal peptides: SignalP 3.0. J Mol Biol 2004; 340:783-795. PubMed http://dx.doi.org/10.1016/j.jmb.2004.05.028

59. Krogh A, Larsson B, von Heijne G, Sonnhammer EL. Predicting transmembrane protein topology with a hidden Markov model: application to complete genomes. J Mol Biol 2001; 305:567580. PubMed http://dx.doi.org/10.1006/jmbi.2000.4315

60. Rutherford K, Parkhill J, Crook J, Horsnell T, Rice P, Rajandream MA, Barrell B. Artemis: sequence visualization and annotation. Bioinformatics 2000; 16:944-945. PubMed http://dx.doi.org/10.1093/bioinformatics/16.10.944

61. Carver T, Thomson N, Bleasby A, Berriman M, Parkhill J. DNA Plotter: circular and linear interactive genome visualization. Bioinformatics 2009; 25:119-120. PubMed http://dx.doi.org/10.1093/bioinformatics/btn578

62. Darling AC, Mau B, Blattner FR, Perna NT. Mauve: multiple alignment of conserved genomic sequence with rearrangements. Genome Res 2004; 14:1394-1403. PubMed http://dx.doi.org/10.1101/gr.2289704

63. Lechner M, Findeiss S, Steiner L, Marz M, Stadler PF, Prohaska SJ. Proteinortho: detection of (Co)orthologs in large-scale analysis. BMC Bioinformatics 2011; 12:124. PubMed http://dx.doi.org/10.1186/1471-2105-12-124 